\title{
Role Analysis of Debt Equity Ratio on Dividend Payout Ratio, Stock Return and Earning Per Share with Firm Size and Return on Equity as Intervening Variable (Case Study of Infrastructure Companies Listed in Indonesia Stock Exchange Year of 2015-2019)
}

\author{
Ulfi Nurfaeda', Tantri Yanuar Rahmat Syah ${ }^{2}$ \\ ${ }^{1,2}$ Graduate Program of Management, Universitas Esa Unggul, Jakarta, Indonesia \\ Corresponding Author: Ulfi Nurfaeda
}

\begin{abstract}
The Indonesian government has been catching up with infrastructure development in recent years. In carrying out infrastructure development, funding and determination of the optimum capital structure are needed because this will affect a company's financial structure. The company's source of funds comes from foreign capital and equity as measured by the debt-to-equity ratio. However, in realizing the optimal determination of capital structure will affect several other financial ratios, therefore the aim of this study is to identify and examine the relationship between DER and DPR, SR and SR which uses FS and ROE as intervening variables. The data used were fourteen companies engaged in building construction and toll road construction. The results of this study indicate that there is a significant positive relationship between DER on FS, ROE, EPS and DPR, FS on EPS and ROE on DPR and EPS. The DER variable on DPR and EPS which is moderated by ROE and FS also has a significant positive relationship. On the other hand, the relationship between FS and DPR and the DER variable against DPR moderated by FS, show a significant negative, while the relationship between DER and SR is negative and insignificant. In addition, the relationship between FS and ROE on SR and DER against SR which is moderated by FS and ROE shows a positive but insignificant
\end{abstract}

Keywords: Debt Equity Ratio, Firm Size Earning Per Share, Return on Equity, Dividend Payout Ratio dan Stock Return.

\section{INTRODUCTION}

In funding, it is necessary to determine the correct capital structure. According to Kusumajaya (2011) decisions in choosing sources of funds are important for every company, because it will impact the company's financial structure and profitability. The company's funding sources consist of foreign capital and equity as measured by the debt-to-equity ratio. The capital structure is a financing consisting of long-term debt, preferred stock, and shareholder capital (Copeland et al., 1999) and capital structure is the combination of debt and equity used to finance a firm's projects. The capital structure of a firm is some mix of debt, internally generated equity, and new equity (Fred, Weston and Copeland, 2012). Whether or not the determination of the capital structure will impact directly the company's financial condition, especially in the presence of a large proportion of debt, it will burden the company. On the other hand, in submitting a tender to carry out a large development work, the determination of the optimal capital structure must be determined because this could reflect how much risk the company will experience a deficit.

According to Utami (2006) with the presence of financial reports it will be used as a medium of communication between company management and external parties. Therefore, the submission of financial 
Ulfi Nurfaeda et.al. Role analysis of debt equity ratio on dividend payout ratio, stock return and earning per share with firm size and return on equity as intervening variable (case study of infrastructure companies listed in Indonesia stock exchange year of 2015-2019).

statements must be presented on time because it will impact on the delay of information obtained. However, in reality there are several construction companies that have off balance sheet of debt financing. This is attractive to companies especially highly leveraged companies. Companies use off balance sheet of debt financing techniques for the purchase of certain assets, especially those with large amounts with the aim that their debt does not exceed the debt covenant limit or so that the company obtains funding with low interest, because if the company's debt is too much, then automatically they would be prone to default. Therefore, they will be subject to higher loan interest rates by investors or bankers.

Basically, the Indonesian government has been catching up with infrastructure development in recent years. Therefore, the Government has prioritized development in order to reduce the gap among regions in Indonesia. Development every year to date has achieved significant progress that can be enjoyed by the Indonesians. Development in the fields of education, toll roads, schools, bridges, dams and others have brought the Indonesians to enjoy a fairly high prosperity compared to the beginning of independence (Sugiyanto, 2019). Therefore companies engaged in building construction and toll road infrastructure development are also experiencing very rapid developments (Umar et al., 2009). The market for building construction or toll road construction in Indonesia has grown significantly, this is driven by several factors such as the rapid growth of the market, public investment in property (real estate) and government spending in the construction of facilities and infrastructure (Tikupadang et al., 2016). Looking at Indonesia's Gross Domestic Product (GDP) data, the construction industry will also contribute $5.7 \%$ of Indonesia's GDP in 2019. For more details, please see the chart below.

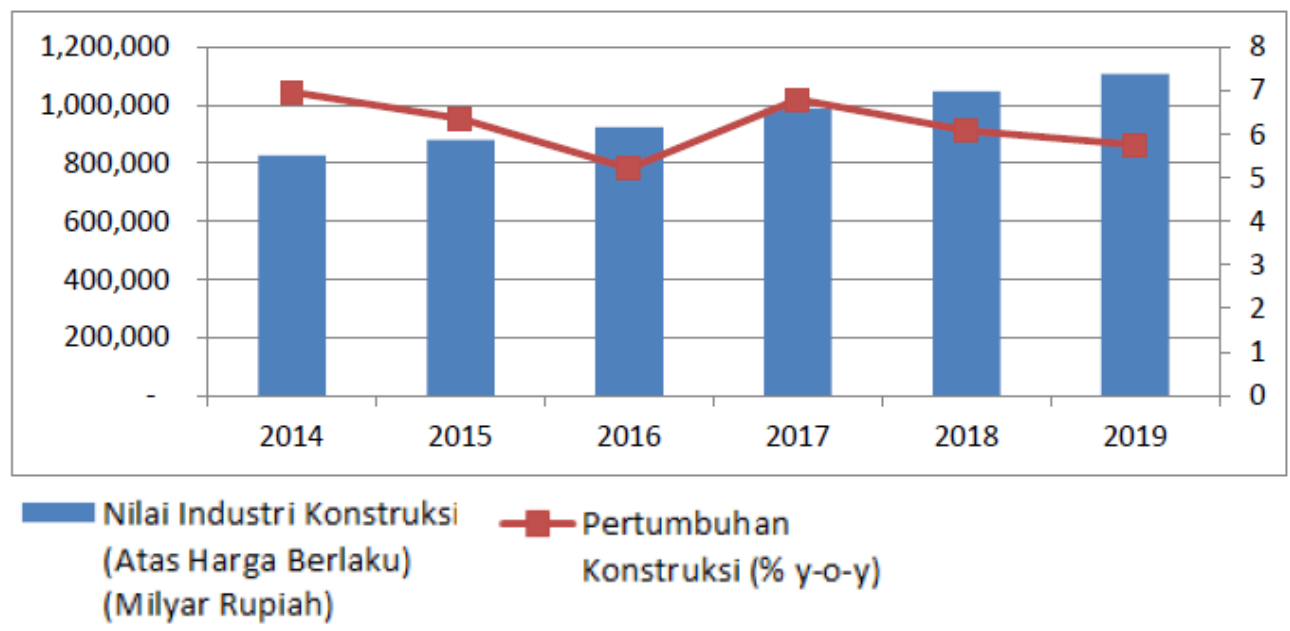

Graph 1.1 Contribution of the Construction Industry in Indonesia Source: Data BPS, Year 2019

As one of the things in support of a development, adequate financing is needed. In terms of planning, building and maintaining infrastructure it will definitely require a very large budget. Infrastructure development is a cost investment that must be issued by the government because the budget still relies more on funding through the APBN and APBD. However, to meet the acceleration of infrastructure development and overcome funding problems, the Government is required to seek creative funding schemes (creative financing), including the cooperation scheme between the Government and Business Entities (PPP) or Public Private Partnership (PPP). There are various types of investment in building construction, which are divided into three categories, namely residential, commercial and industrial property (Thomsett, 2012). 
Ulfi Nurfaeda et.al. Role analysis of debt equity ratio on dividend payout ratio, stock return and earning per share with firm size and return on equity as intervening variable (case study of infrastructure companies listed in Indonesia stock exchange year of 2015-2019).

According to Lie et al. (2018) Investment policy is the most important of the two financial policies, namely the funding policy (funding) and dividend policy. However, by implementing a funding policy, the construction company will have debt.

In research conducted by Basit Abdul \& Hasan Zubair (2018) There is a relationship between debt to equity ratio (DER) to firm size (FS), earnings per share (EPS) and return on equity (ROE). Besides that in several previous studies carried out by Gleason et al. (2015), Zeitun \& Tian (2007) explained the effect between DER on FS. On research carried out by Nopiyah (2017) and Susilawati (2014) explained the effect of DER on EPS and in research Ismi et al., (2016) stated that there is a relationship between DER and ROE. In addition, research results carried out by Gugler et al., (2011) and Kowalewski et al., (2011) stated that there is a relationship between FS and the DPR and the research results from carried out by Martani \& Khairurizka (2009) and Acheampong et al. (2014) explained the relationship between FS and EPS. Results of research carried out by Kumala et al. (2014) and Nugrahani (2016) stated that there is a relationship between FS and EPS and research carried out by lawrence O Karani (2015) and Nurhikmawaty et al.,(2020) explained the effect of ROE on DPR. Other studies carried out by Nurhikmawaty et al., (2020) and Hanani (2011) who argued that there is a relationship between ROE and SR as well as research conducted by Taani et al., (2011) which stated the effect between ROE variable on EPS.

However, in previous studies there were still not many studies that made FS and ROE as intervening variables that connected the DER variable to DPR, SR and EPS. In addition, previous studies were mostly conducted in the chemical, food and pharmaceutical sectors, while this research was conducted in the Building Construction and Toll Road Sector. The purpose of this study is to identify and examine the interrelated relationships among DER, FS,
ROE, DPR, SR and EPS variables. It is expected that this research can provide information for stakeholders and potential investors to serve as a basis for making a decision.

\section{LITERATURE REVIEW Capital Structure}

Capital structure is the proportion among debt, preference shares, common stock that the company wants in its capital structure (Bringham, Eugene F and Weston, 2011). Capital structure deals with longterm financing with own capital (Sudana, 2011). The capital structure provides an overview to the company regarding the company's funding sources which consist of debt and company capital. The results of determining the mix of funding sources will be used by the company to maximize firm value or maximize the value of the company's stock market price. The optimal capital structure is a capital structure that optimizes the balance between risks and returns so as to maximize share prices (Margaretha, 2011). In this case, there are several capital structure theories used in this study, including the Traditional Approach, Pecking Order Theory and Signaling Theory. If the use of debt is fairly high, the value of the company will decrease because the debt becomes higher, the cost of capital increases making the risk of using debt be higher and the cost of share capital also increases. (Brigham and Joel F. Houston, 2011). In addition there is also a Pecking Order Theory put forward by Myers, S.C and Majluf (1984). The pecking order theory explains specifically, companies have a preference order in the use of funds. The company will choose to issue debt first rather than issue shares when it needs external funding.

\section{Debt Equity Ratio (DER)}

Werner and Jones (2003), DER showed a proportional relationship between debt and equity. Lower DER means total debt is relatively lower than total equity, because with an increase in DER, the 
Ulfi Nurfaeda et.al. Role analysis of debt equity ratio on dividend payout ratio, stock return and earning per share with firm size and return on equity as intervening variable (case study of infrastructure companies listed in Indonesia stock exchange year of 2015-2019).

company increases equity risk. Generally, higher DER companies always have a higher risk and DER is expected to be positively correlated with general equity risk across the company. Therefore, DER is proposed as an additional variable to explain the expected return on common stock (Bhandari, 1988). According to Brigham \& Joel (2009) and Kasmir (2011) with the DER, it will be able to measure how far the company uses funding through debt and measure the company's ability to meet its obligations if the company is liquidated (Sutrisno, 2009). The use of debt that is too large will endanger the company because the company will be in the extreme leverage category, that is, the company is trapped in high debt and it is difficult to release the debt burden. (Fahmi, 2013). In this study, the formula used to calculate the total debt ratio was divided by liabilities to equity or capital. This is in accordance with one study carried out by Nerviana (2016) who used the same formula.

\section{Size Firm}

Nerviana (2016) said firm size has a big role to play in the decision what kind of dividend policy to use. Most of the research have shown that firm size has a proportional relationship with the number of dividends paid. In general, the bigger the company, the higher and the more frequent its cash flow, which leads to a better return on investment. Banerjee \& De (2015) firm size is considered as an important variable that influences the company's dividend payout. It can be assumed that long-established companies and large corporations will pay larger dividends to shareholders, while newer, smaller companies will pay smaller dividends to shareholders and will retain more for growth and expansion in the future. In this study, the formula used to calculate Firm Size was the natural log of total assets and market capitalization as a substitute for company size. The formula used is in accordance with previous research, namely (Ahmad \& Wardani,
2014), (Misra \& Anil, 2010) and (Banerjee \& De, 2015).

\section{Earnings Per Share (EPS)}

EPS describes the company's profitability as reflected on each share. With a fairly high demand for shares, it will have an impact on increasing the stock price itself and high profitability will have an impact on the company's good prospects. EPS is always reported on every financial report, therefore according to the signaling theory it is closely related to financial statement information, so it's good from the start of a business, a company has good and easy books, so that it can be used as financial information both internally and externally. (Ross, 1977). EPS in the form of profit which is the right of each holder of one common share. Prastowo \& Julianti (2005) the higher the company's ability to distribute its income to shareholders, the greater the success of the company. An increase or decrease in the stock price of a company on the Stock Exchange shows the ups and downs in the value of the company. Murhadi (2013), said the EPS of a company can see the company's financial statements in the income statement section. If prospective shareholders are interested in investing in shares, they can look at the EPS section, because this is an indicator of the success of a company. EPS can show the level of welfare of a company, so if the EPS distributed to shareholders or investors is high, it indicates that the company is able to provide a good level of welfare to shareholders. This means that companies that have a good performance will also increase the EPS distributed to shareholders or investors. In this study, the formula used to calculate EPS is the amount of net income divided by the number of shares outstanding. The formula used is in accordance with previous research, namely (Brigham, 2010).

\section{Return on Equity (ROE)}

Kasmir (2012), ROE is a ratio that can measure net profit after tax with own 
Ulfi Nurfaeda et.al. Role analysis of debt equity ratio on dividend payout ratio, stock return and earning per share with firm size and return on equity as intervening variable (case study of infrastructure companies listed in Indonesia stock exchange year of 2015-2019).

capital. This ratio shows the efficient use of own capital. The higher this ratio, the better. This means that the position of the company owner is getting stronger, and vice versa. In this study, the formula used to calculate ROE is net income divided by total equity or capital. The formula used is in accordance with previous research, namely (Nerviana, 2016).

\section{Dividend Payout Ratio (DPR)}

According to Gordon (1956) and Lintner (1962), which is commonly called the Bird In The Hand Theory states that investors prefer cash dividends rather than being promised a return on investment (capital gain) in the future, because receiving cash dividends is a form of certainty, which means that it will reduce the level of risk. Dividends are payments from company income or profits that are distributed to shareholders in cash or shares. A company's dividend policy refers to its choice of whether to pay cash dividends to shareholders, how much cash dividends should be, and how often it should be distributed. (Smart, Scoot B, William L megginson, Lawrence J, 2004). Dividend payout rates can indicate that companies that have high interest and dividend payout rates use more debt financing than those with less dividend payments. (Pruitt \& Gitman, 1991). In this study, the formula used to calculate the DPR is cash dividends divided by net income.

\section{Stock Return}

According to the Theory of Information Asymmetry and Signaling, it is stated that the capital structure is a signal that is conveyed by managers to the market. If the manager believes that the company's prospects are good and wants the shares to increase, then this will be communicated to investors. Managers can use more debt as a more credible signal. Because companies that increase debt can be seen as companies that are confident in the company's prospects in the future. Investors are expected to pick up on these signals, a signal that the company has good prospects (Ross, 1977).

Then the demand for a lot of shares will make the stock price increase. High profitability shows that the company's prospects are good, so investors will respond positively to these signals and the company's value will increase. This is because signaling theory has a close relationship with financial statement information (Ross, 1977)

Brigham. Eugene F. and Joel F. Houston (2009), The rate of return is the difference between the amount received and the amount invested, divided by the amount invested. Meanwhile, according to Jogiyanto (2009) return is the result obtained from investment. The formula used to calculate Stock Return is the stock price in period $\mathrm{t}$ minus the stock price in the previous period and then divided by the share price in the previous period.

\section{METHODOLOGY}

Based on the data obtained, this research is quantitative because it refers to the calculation of research data which is numerical and requires a systematic approach. The variables used in this study consisted of six variables, namely DER, FS, ROE, DPR, SR and EPS. The population used in this study is infrastructure companies which are building construction companies and toll road companies that have been listed on the Indonesia Stock Exchange. While the sampling in this study using purposive sampling, thus obtained fourteen companies used in this study. 
Ulfi Nurfaeda et.al. Role analysis of debt equity ratio on dividend payout ratio, stock return and earning per share with firm size and return on equity as intervening variable (case study of infrastructure companies listed in Indonesia stock exchange year of 2015-2019).

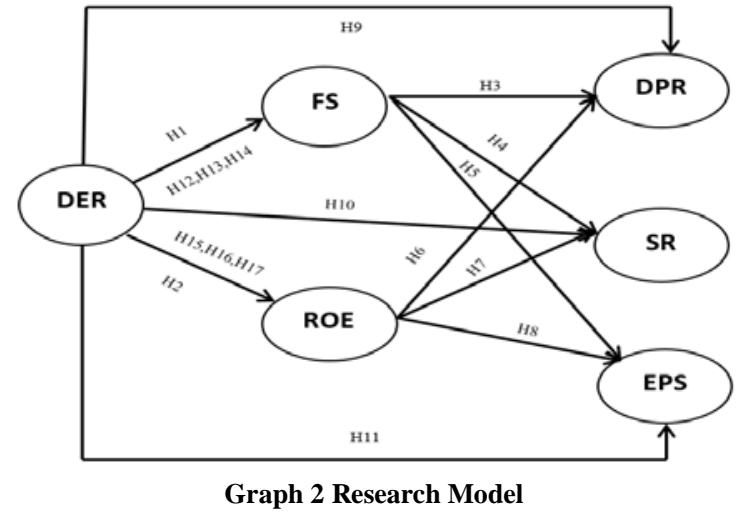

The purpose of this study is to identify and examine the interrelated relationships between DER, FS, ROE, DPR, SR and EPS variables. In addition, FS and ROE were also used as intervening variables that connected the DER variable to DPR, SR and EPS. The method used in the analysis in this study was the Structural Equation Modeling Partial Least Square (SEM-PLS) method. In using this model data input was carried out, where the data used were selected based on data without outliers, then analysis of validity and reliability tests, discriminant validity, goodness of fit, direct effect and specific indirect effect was carried out.

\section{ANALYSIS \& DISCUSSION}

Validity \& Reliability Test - In this test the indicator is declared valid because the value of Average Variance Extracted (AVE) is above 0.5 and the value of Cronbach's alpha is above 0.7. Discriminant Validity Test - In this test the indicator is declared valid if the discriminant value of the latent variable (construct) on the indicator must be greater than the correlation of the indicator with other latent variables. The results of data processing show that the correlation value of latent variables with their indicators is greater than the correlation of indicators to other latent variables thus they are declared valid. Goodness of Fit - The results of goodness of fit model or $\mathrm{R}$ Square test in appendix 5 section E, showed that the DPR variable was 0.357 or $35.7 \%$, this means that there are other variables outside of this study not examined as much as $64.3 \%$, for $\mathrm{R}$ square EPS of 0.703 or $70.3 \%$, which means that the variables that have not been studied outside this study was $29.7 \%$. The FS variable had an R Square of 0.480 or $48 \%$, which means that there are other variables outside this study not examined as much as $52 \%$, the ROE variable was 0.184 or $18.4 \%$ which means there are other variables outside this research not examined as much as $81,6 \%$, and the SR variable was 0.035 or $3.5 \%$, this means that there are still other variables outside this study not examined as much as $96.5 \%$.

Hypothesis Test - This study was conducted using data processing SEM-PLS method, where the results of this study were nine hypotheses accepted and eight hypotheses rejected. For more details, see the table below.

Table 1. Hypothesis Test Results

\begin{tabular}{|c|c|c|c|}
\hline Hypothesis & $\begin{array}{l}\text { Original } \\
\text { Sample }\end{array}$ & $\begin{array}{l}\mathbf{P} \\
\text { Value } \\
\end{array}$ & $\begin{array}{l}\text { Hypothesis } \\
\text { Test Results }\end{array}$ \\
\hline $\begin{array}{l}\text { H1: DER has a positive } \\
\text { relationship on FS }\end{array}$ & 0.693 & 0.000 & Accepted \\
\hline $\begin{array}{l}\text { H2: DER has a positive } \\
\text { relationship on ROE }\end{array}$ & 0.429 & 0.000 & Accepted \\
\hline $\begin{array}{l}\text { H3: FS has a positive } \\
\text { relationship on DPR }\end{array}$ & -0.488 & 0.000 & Rejected \\
\hline $\begin{array}{l}\text { H4: FS has a positive } \\
\text { relationship on SR }\end{array}$ & 0.242 & 0.233 & Rejected \\
\hline $\begin{array}{l}\text { H5: FS has a positive } \\
\text { relationship on EPS }\end{array}$ & 0.590 & 0.000 & Accepted \\
\hline $\begin{array}{l}\text { H6: ROE has a positive } \\
\text { relationship on DPR }\end{array}$ & 0.465 & 0.000 & Accepted \\
\hline $\begin{array}{l}\text { H7: ROE has a positive } \\
\text { relationship on SR }\end{array}$ & 0.008 & 0.959 & Rejected \\
\hline $\begin{array}{l}\text { H8: ROE has a positive } \\
\text { relationship on EPS }\end{array}$ & 0.206 & 0.018 & Accepted \\
\hline $\begin{array}{l}\text { H9: DER has a negative } \\
\text { impact on DPR }\end{array}$ & 0.414 & 0.000 & Rejected \\
\hline $\begin{array}{l}\text { H10: DER has a } \\
\text { positive impact on SR }\end{array}$ & -0.102 & 0.516 & Rejected \\
\hline $\begin{array}{l}\text { H11: DER has a } \\
\text { positive impact on EPS }\end{array}$ & 0.194 & 0.05 & Accepted \\
\hline $\begin{array}{l}\text { H12: FS can be used as } \\
\text { an intervening variable } \\
\text { between DER and DPR }\end{array}$ & -0.338 & 0.000 & Rejected \\
\hline $\begin{array}{l}\text { H13: FS can be used as } \\
\text { an intervening variable } \\
\text { between DER and SR }\end{array}$ & 0.168 & 0.264 & Rejected \\
\hline $\begin{array}{l}\text { H14: FS can be used as } \\
\text { an intervening variable } \\
\text { between DER and EPS }\end{array}$ & 0.408 & 0.000 & Accepted \\
\hline $\begin{array}{l}\text { H15: ROE can be used } \\
\text { as an intervening } \\
\text { variable between DER } \\
\text { and DPR }\end{array}$ & 0.199 & 0.004 & Accepted \\
\hline $\begin{array}{l}\text { H16: ROE can be used } \\
\text { as an intervening } \\
\text { variable between DER } \\
\text { and SR }\end{array}$ & 0.003 & 0.960 & Rejected \\
\hline $\begin{array}{l}\text { H17: ROE can be used } \\
\text { as an intervening } \\
\text { variable between DER } \\
\text { and EPS }\end{array}$ & 0.088 & 0.006 & Accepted \\
\hline
\end{tabular}


Ulfi Nurfaeda et.al. Role analysis of debt equity ratio on dividend payout ratio, stock return and earning per share with firm size and return on equity as intervening variable (case study of infrastructure companies listed in Indonesia stock exchange year of 2015-2019).

\section{Analysis on the Effect of Debt-to-Equity Ratio on Firm Size}

The results of the analysis showed that the DER relationship with FS had a significant positive effect, which means that the first hypothesis is accepted. This is evidenced by 0.693 (positive direction) with a significance value of 0.000 less than 0.05 (level of significant). Basically, according to Goyal (2013), firm size is expected to be a very important indicator in measuring the performance of a company. The debt-toequity ratio will have a positive impact on the size of the company as a player in large companies that is better than small companies on economies of scale as well as economic recession. This will lead to a more efficient company performance which will have an impact on accounting profits. In addition, with the higher proportion of debt, the company will increase its assets in order to increase its efficiency. In accordance with the results of research conducted by Gleason et al. (2015) and Zeitun \& Tian (2007), where debt to equity ratio has a positive relationship to a firm size.

\section{Analysis on the Effect of Debt To Equity Ratio to Return On Equity}

The results of the analysis showed that the DER relationship to ROE had a significant positive effect, which means that the second hypothesis is accepted. This is evidenced by 0.429 (positive direction) with a significance value of 0.000 less than 0.05 . This means that if DER has increased, it will also be followed by an increase in ROE, and vice versa. The greater the proportion of debt used for the capital structure of a company, the greater the probability of the level of profit that is obtained. This is in accordance with the balancing theory which states that debt is allowed as long as the level of profit earned exceeds the cost of debt. The DER variable has the most dominant influence on ROE, so the DER variable needs attention. The results of this study are in accordance with Ismi et al., (2016) which stated that there is a positive and significant influence between
DER on ROE. However, the results of this study differ from the results Arimi (2010) and Fama \& French (2007), which stated that there is a significant negative relationship between DER and ROE.

\section{Analysis on the Effect of Firm Size on Dividend Payout Ratio}

The FS variable has a negative and significant effect on the DPR variable. With these results, it is concluded that the third hypothesis is rejected. This can be seen from the original results of the sample variable FS showed -0.488 with a significance level of 0.00 which is smaller than 0.05 . The results of this study show that it is in accordance with the results of the study conducted by Pribadi \& Sampurno (2012) and Michell \& Sofyan (2004) which stated that there is a significant negative influence between FS on the DPR. This may be due to the company's decision regarding the benefits, as disclosed by T. Kowalewski (2007) which states that a company with a high size and good investment possibilities, will pay smaller dividends. According to Brigham, E.F., and Ehrhardt (2002) which stated that the larger the size of the company, the more likely it is to pay low dividends with the aim of reducing the company's dependence on external funding. But the inconsistency of the statement from Gugler et al., (2011), Kowalewski et al., (2011), Marietta (2013) and Atmoko et al., (2018) who argued that FS has a positive and significant effect on the Dividend Payout Ratio policy.

\section{Analysis on the Effect of Firm Size on Stock Return}

The results of the analysis of the relationship between FS and SR showed 0.242 (positive direction), but the P-Value in this hypothesis test was 0.233 which indicates that the fourth hypothesis was rejected. So, it can be said that Firm Size has no effect on Stock Returns. Therefore, investors do not take into account the size of the company in deciding to purchase shares. Basically, a firm size can be classified by 
Ulfi Nurfaeda et.al. Role analysis of debt equity ratio on dividend payout ratio, stock return and earning per share with firm size and return on equity as intervening variable (case study of infrastructure companies listed in Indonesia stock exchange year of 2015-2019).

the size of the company through total assets, net sales, and market capitalization. Large companies will easily obtain additional funds in the capital market compared to small companies. (Sartono, 2010). However, investors should not only look at a company on its size, large companies do not always have a large total asset of the capital they have, the capital they have may come from loans that will have to be paid which will result in a small return or return on shares. (Mayuni et al., 2018). The company's growth is not only based on the size of the company, because the size of an asset owned by the company, if it is not managed properly by the operations of a company, will not be able to generate large profits. Profits that are not maximum will have an effect on declining share prices. Therefore, the size of an asset owned by a company will not be able to predict the amount of profit that will be obtained by the company and the return that will be obtained by investors. This has an impact on investors' less interest in seeing the size of the assets owned by the company in making an investment decision (Setiyono, 2016). A research conducted by Martani \& Khairurizka (2009), Acheampong et al. (2014), Mazviona (2014), (Dwi et al., 2020), Puspita, (2012) concluded that firm size has no significant positive effect on stock returns.

\section{Analysis on the Effect of Firm Size on Earning Per Share}

The results on the calculation showed that the variable firm size calculated by Ln Total Assets was 0.590 (positive direction) with a significance value of 0.000 , less than 0.05 , meaning that company size has a positive effect on earnings per share. The firm size shows the financial capability of the company, where large companies are more capable and more stable in generating profits than small companies. A company with a high company size means that it has large total assets, thus indicating that the company has more productive assets in generating profits.
In this study, firm size is measured using total assets. Large companies generally have large total assets and will be better able to improve performance and increase profits if the company can use these assets optimally. Nugrahani (2016) The results of this study are in line with research conducted by Nugrahani (2016) who stated that there is a positive relationship of firm size on earning per share. This shows the ability of the company to be able to use the loan obtained effectively in increasing profits, so the size of the loan obtained can affect the EPS distributed.

\section{Analysis on the Effect of Return on Equity on Dividend Payout Ratio}

The results of the analysis between the ROE variable have a significant positive effect on the DPR. Where when the company's ROE increases, the dividend payout ratio will also increase. Vice versa, when ROE decreases, the dividend payout ratio also decreases. According to Kristina et al., (2017) dividend is a portion of the net profit earned by the company. Therefore, dividends will be distributed to investors if the company makes a profit. In accordance with the Signaling Hypothesis or Information Content theory by MondiglianiMiller which states that an increase in earnings indicates that managers predict a good income in the future for investors through an increase in dividends.

Companies that are able to generate profits and are able to stabilize the level of profits to be obtained can determine how much dividends will be distributed to investors. The prospect of next year's profit is also a major factor in the amount of dividends that will be distributed this year. If the management believes they can make a profit next year, then it is certain that dividends will certainly increase (Nurhikmawaty et al., 2020). This is in accordance with the research conducted by Lawrence O Karani (2015), Nurhikmawaty et al., (2020), Kristina et al., (2017) and Nerviana (2016) the higher the ROE will 
Ulfi Nurfaeda et.al. Role analysis of debt equity ratio on dividend payout ratio, stock return and earning per share with firm size and return on equity as intervening variable (case study of infrastructure companies listed in Indonesia stock exchange year of 2015-2019).

increase the chances of high dividend payments.

\section{Analysis on the Effect of Return on Equity on Stock Return}

Based on the calculation results, it can be seen that the significance value was $0.959>0.05$ and the original sample value was 0.008 in a positive direction. This shows that ROE has no significant positive effect, or in other words, ROE has no effect on stock returns. The results of this study did not support the research conducted by Nurhikmawaty et al., (2020), Hanani (2011), Carlo (2014) and Untu et al., (2015) which stated that there is a significant positive relationship between return on equity to stock returns. However, the results of this study strengthen the research conducted by Dwi et al., (2020), Inka et al., (2013) and Ayu et al., (2016) in his research found that ROE has no significant effect on stock returns. ROE can be large because the profit increases or the capital decreases. Decreasing capital in a company allows the company to have debt. However, the research results showed that return on equity has no effect on stock returns, meaning that the level of ROE will not affect investors in making investment decisions, because if the company is able to manage its capital properly it will be able to generate profits. So not all companies whose capital decreases will have an effect on the company's stock returns (Wiagustini, 2010)

\section{Analysis on the Effect of Return on Equity on Earning Per Share}

The relationship between ROE and EPS has a significant positive effect because the sig value is smaller than the probability value of 0.05 or the value of $0.018<0.05$ and the original sample value is 0.206 (positive direction). The positive effect of ROE shows that the profitability generated by the capital itself is quite productive and is able to contribute to earnings per share.

Profitability ratios measure management effectiveness based on the returns obtained from sales and investment.
The profitability of a company will affect the policies of investors on the investment made. ROE is a profitability ratio that can be used to measure how effectively the equity provided by investors and managed by management to operate to generate profits. The results of this study indicate that the higher the ROE value, the more efficient the company uses its own capital to generate and increase profits. This higher ROE indicates that the company can get greater returns (Ayu et al., 2016).

The results of this study support the research conducted by Taani et al., (2011) which stated that a higher ROE indicates a higher efficiency in spending money invested by shareholders for profit growth. Thus, it can be concluded that in this study the increase in EPS is obtained from an increase in ROE. This is because a high ROE can cause companies to easily attract new funds. Besides the research results conducted by Kumala Shinta (2014) which stated that the higher the ROE value, the more efficient the company uses its own capital to generate and increase profits. This is because a high ROE can cause the company to easily attract new funds to develop and earn greater profits, thereby increasing the amount of profit available to shareholders. The company's ability to generate profits will be able to attract investors to invest their funds to expand their business, on the other hand, a low level of profitability will cause investors to withdraw their funds. Therefore, profitability has an important meaning in an effort to maintain its survival in the longterm, because profitability shows whether the business entity has good prospects in the future.

\section{Analysis on the Effect of Debt Equity Ratio on Dividend Payout Ratio}

The results on the analysis of the relationship between the DER variable and the DPR are positive and significant with a significant value of 0.000 and 0.414 (positive direction). So, the lower the DER, the higher the company's ability to pay all of 
Ulfi Nurfaeda et.al. Role analysis of debt equity ratio on dividend payout ratio, stock return and earning per share with firm size and return on equity as intervening variable (case study of infrastructure companies listed in Indonesia stock exchange year of 2015-2019).

its obligations. This is because the lower the proportion of debt used for the capital structure of a company, the lower the amount of liabilities. The results of this study was not in line with those conducted by Nerviana (2016) it was found that there was a negative and significant relationship between DER and DPR. But in line with what was done by Jensen, M.C (1976), Atmoko et al., (2018) and Firmansyah et al., (2010) who obtained the results that DER has a positive and significant effect on the DPR. The significance of the DER variable on the DPR variable obtained in this study shows that there are different views of investors in their consideration of the DER position. This indicates that the dividend payment policy, which is the responsibility of the company, is related to the loans made, making the company view that this condition can increase funds for the company as capital for business growth which can later be used to increase dividend payments.

\section{Analysis on the Effect of Debt Equity Ratio on Stock Return}

Based on the results of hypothesis testing, it shows that DER has no significant effect on stock returns. This means that the high and low DER values will not affect the SR value. SR is the difference between the purchase price and the selling price. If the purchase price is lower than the selling price, you will get a capital gain. Likewise, vice versa, if the purchase price is higher than the selling price, you will get a capital loss. To get the maximum rate of return, investors must have knowledge of the technical analysis used to maximize profits. The factor of high and low debt is not used as a standard for investors, but buying and selling activities carried out by other investors in stock trading activities. The things that will affect the increase in the price of shares depend on how many people buy shares at that time, and vice versa. The results of this study are supported by several previous studies, namely Sinaga (2019), and Hanani (2011). This was contrary to the results of research by Khan et al. (2013) and Jane et al.(2017), which stated that DER has a significant effect on stock returns.

\section{Analysis on the Effect of Debt To Equity Ratio on Earning Per Share}

The results of this test indicate that the hypothesis is accepted. The results of statistical tests showed that there is a significant influence between DER and EPS with a significance value of 0.005 . A high DER ratio indicates that companies use debt financing rather than equity financing in carrying out their operating activities. The use of this loan capital will further increase the risk of loan non-payment. However, in investing, a riskier decision is expected to provide greater returns, which in financial terms is known as "high risk high return". In addition, even though the decision to increase debt will have a negative impact, the company is trying to balance the benefits arising from debt. As long as the benefits are still far greater than the cost of debt, the debt can be added. This is in line with the research results conducted by Taani et al., (2011) which stated that the high use of debt is used to support long-term growth for the company to make a profit. So, it can be concluded that the increase in EPS in this study was obtained because the company managed to manage its debt well. This is because the income obtained from the use of funds is greater than fixed expenses (interest). According to Yuliandri et al., (2012), for companies that are able to bear interest expense from the use of debt, the use of leverage is considered to increase EPS. This is supported by the results of research by Nopiyah (2017), Susilawati (2014) Kumala Shinta (2014) and Eka Susilawati (2014) that there is a significant positive effect of DER on EPS.

\section{FS can be used as an intervening variable between DER and DPR}

Based on the results of the indirect effect calculation, FS as an intervening variable of DER to the DPR obtained the original sample value of -0.338 with a 
Ulfi Nurfaeda et.al. Role analysis of debt equity ratio on dividend payout ratio, stock return and earning per share with firm size and return on equity as intervening variable (case study of infrastructure companies listed in Indonesia stock exchange year of 2015-2019).

significance value (p-value) of 0.000 . Although the significant value is less than 0.05 , the proposed hypothesis is rejected because the variable relationship is mutually weakening. When viewed from the direct effect between DER and FS, it has a significant positive relationship, which means that if the DER level gets bigger it will also affect the DPR level. Meanwhile, if viewed from the direct effect between FS and DPR, it has a significant negative relationship, which means that if the FS level is higher, the lower the level of the DPR will be. This may be due to the company's decision regarding the benefits, as disclosed by T. Kowalewski (2007) which stated that a company with a high size and good investment possibilities, will pay smaller dividends. According to Brigham, E.F., and Ehrhardt (2002) which stated that the bigger the firm size, then it has a tendency to pay low dividends in order to reduce the company's dependence on external funding. These results differ according to the results of the study Lia (2017) where DER has a significant positive effect on the DPR through FS as an intervening ratio variable in manufacturing companies in the food and beverage subsector in 2012-2016.

\section{FS can be used as an intervening variable between DER and SR}

Based on the results of the calculation of indirect FS as an intervening variable DER to $\mathrm{SR}$, the original sample value was 0.168 (positive direction) with a significance value of 0.264 . Basically, when viewed from the direct effect of DER on FS, it has a significant positive relationship. The debt-to-equity ratio will have a positive impact on the size of the company as a player in large companies that is better than small companies on economies of scale as well as economic recession. This will lead to a more efficient company performance which will have an impact on accounting profits. In addition, with the higher proportion of debt, the company will increase its assets in order to increase its efficiency.

However, when viewed from the direct effect of FS on SR, it shows a value of 0.242 (positive direction), but the P-value in this hypothesis test was 0.233 . So, it can be said that company size has no significant effect on stock returns. Large Companies have greater access to sources of funding from various sources, therefore obtaining loans from creditors will be easier because companies with large sizes have a greater probability of winning the competition or staying in the industry.

On the other hand, small-scale companies are more flexible in dealing with uncertainty, because small companies react quicker to sudden changes. Therefore, it is possible for large companies to have a greater level of leverage than small companies (Puspita, 2012b). Thus, it can be concluded that the proposed hypothesis is rejected, where FS cannot be used as an intervening variable between DER and SR in building construction companies and toll road companies on the IDX 2015-2019.

\section{FS can be used as an intervening variable between DER and EPS}

Based on the results of the indirect calculation, FS as an intervening variable of DER to EPS obtained the original sample value of 0.408 (positive direction) with a significance value of 0.000 . This means that the FS variable can be used as an intervening variable between DER and EPS. That way, if the company wants to get a greater value of earnings per share, it requires an addition of total assets where the costs used for adding both current and noncurrent assets come from loans from external parties. Therefore, the proposed hypothesis is accepted, where FS can be used as an intervening variable between DER and EPS in building construction companies and toll road companies on the IDX in 2015-2019. 
Ulfi Nurfaeda et.al. Role analysis of debt equity ratio on dividend payout ratio, stock return and earning per share with firm size and return on equity as intervening variable (case study of infrastructure companies listed in Indonesia stock exchange year of 2015-2019).

ROE can be used as an intervening variable between DER and DPR

Based on the results of indirect calculations, ROE as an intervening variable DER to the DPR obtained the original sample value of 0.199 with a significance value of 0.004 . From the results of these calculations, it can be concluded that ROE can be used as an intervening variable of DER against the DPR in building construction companies and toll road companies on the IDX in 2015-2019.

This indicates that if the company wants to increase the distribution of dividends for shareholders, it can be done by increasing the rate of return on capital. In increasing the return on capital, it is necessary to have the amount of net profit received, which in this case requires a loan from external parties to assist the company in carrying out operational activities. However, this is contrary to the results of the study carried out by Achmad Kautsar, (2013) where ROE cannot be used as an intervening variable between DER and DPR in Non-Financial Companies Listed on the IDX 2009-2011.

\section{ROE can be used as an intervening variable between DER and SR}

Based on the results of the analysis table indirectly, where ROE as an intervening variable DER to SR obtained the original sample value of 0.003 with a significance value of 0.960 . This means indicating that the hypothesis is rejected. When viewed from the analysis table directly between DER and ROE, has a significant positive effect. This is evidenced by 0.429 (positive direction) with a significance value of 0.000 less than 0.05 (level of significance). This means that if DER has increased, it will also be followed by an increase in ROE, and vice versa.

However, when viewed from the analysis table directly between ROE and $\mathrm{SR}$, it has a significance value of $0.959>$ 0.05 and the original sample value of 0.008 in a positive direction. This shows that ROE has no significant positive effect, or in other words, ROE has no effect on stock returns. ROE can be large because the profit increases or the capital decreases. Decreasing capital in a company allows the company to go into debt. However, the research results showed that return on equity has no effect on stock returns, meaning that the level of ROE will not affect investors in making investment decisions, because if the company is able to manage its capital properly it will be able to generate profits. So not all companies whose capital decreases will have an effect on the company's stock returns (Wiagustini, 2010). By doing so, it indicates that the hypothesis is rejected. Therefore, it can be concluded that ROE cannot be used as an intervening variable between DER and SR in building construction companies and toll road companies on the IDX in 2015-2019.

\section{ROE can be used as an intervening variable between DER and EPS}

Based on the results of the analysis table indirectly, where ROE as an intervening variable of DER to EPS, the original sample value was 0.088 with a significance value of 0.006 . This indicates that if the company wants to get greater earnings per share, it can be done by increasing the rate of return on capital. In increasing the return on capital, it is necessary to have the amount of net profit received, which in this case requires a loan from external parties to assist the company in carrying out operational activities. Thus it can be concluded that ROE can be an intervening variable between DER and EPS in building construction companies and toll road companies on the IDX in 2015-2019.

\section{CONCLUSION}

The empirical results of this study are that there is a significant positive relationship between DER on FS, ROE, EPS and DPR, FS on EPS, and ROE on DPR and EPS, while the variables FS and ROE on SR show that there is no significant positive relationship. The relationship between FS and DPR shows a significant negative. On 
Ulfi Nurfaeda et.al. Role analysis of debt equity ratio on dividend payout ratio, stock return and earning per share with firm size and return on equity as intervening variable (case study of infrastructure companies listed in Indonesia stock exchange year of 2015-2019).

the other hand, the relationship between DER and SR shows negative and insignificant. For FS and ROE as intervening variables between DER on EPS and DPR and it shows a significant positive relationship. This means that these variables are simultaneously positively related by strengthening each other between variables. Then if seen from the direct relationship, between these variables has a significant positive relationship.

However, the relationship between DER and DPR mediated by FS shows a significant negative relationship, meaning that the variables are interrelated but weaken each other between variables. On the other hand, the FS and ROE variables cannot be used as an intervening variable between DER and SR.

\section{Acknowledgement: None}

\section{Conflict of Interest: None}

\section{Source of Funding: None}

\section{REFERENCES}

1. Acheampong, P., Agalega, E., \& Shibu, A. K. (2014a). The Effect of Financial Leverage and Market Size on Stock Returns on the Ghana Stock Exchange: Evidence from Selected Stocks in the Manufacturing Sector. International Journal of Financial Research, https://doi.org/10.5430/ijfr.v5n1p125

5(1).

2. Acheampong, P., Agalega, E., \& Shibu, A. K. (2014b). The Effect of Financial Leverage and Market Size on Stock Returns on the Ghana Stock Exchange: Evidence from Selected Stocks in the Manufacturing Sector. International Journal of Financial Research, 5(1), 125-134. https://doi.org/10.5430/ijfr.v5n1p125

3. Achmad Kautsar. (2013). Analisis Pengaruh Firm Size, Der, Dan Sales Growth Terhadap Dividend Payout Ratio Dengan Roe Sebagai Variabel Intervening Pada Perusahaan Non Keuangan Yang Listed Di BEI Tahun 20092011.

4. Ahmad, G. N., \& Wardani, V. K. (2014). the Effect of Fundamental Factor To Dividend Policy: Evidence in Indonesia
Stock Exchange. International Journal of Business and Commerce, 4(402), 2225243614. www.ijbcnet.com

5. Arimi, J. K. (2010). The Relationship Between Capital Structure And Financial Performance: A Study Of Firms Listed Under Industrial And Allied Sector At The Nairobi Stock Exchange 2004 - 2008. November.

6. Atmoko, Y., Defung, F., \& Tricahyadinata, I. (2018). Pengaruh return on assets, debt to equity ratio, dan firm size terhadap dividend payout ratio. Kinerja, 14(2), 103. https://doi.org/10.29264/jkin.v14i2.2486

7. Ayu et al. (2016). Pengaruh Return On Equity, Earning Per Share, Firm Size Dan Operating Cash Flowterhadap Return Saham.

8. Banerjee, A., \& De, A. (2015). Capital Structure Decisions and Its Impact on Dividend Payout Ratio during the Pre- and Post-period of Recession in Indian Scenario: An Empirical Study. Vision: The Journal of Business Perspective, 19(4), 366-377. https://doi.org/10.1177/0972262915610956

9. Basit Abdul \& Hasan Zubair. (2018). Impact of Capital Structure on Firm Performance: Analysis of Food Sector Listed on Karachi Stock Exchange. International Journal of Multidisciplinary Consortium, 1(1), 1-11.

10. Bhandari, L. C. (1988). Debt/Equity Ratio and Expected Common Stock Returns: Empirical Evidence. The Journal of Finance, 43(2), 507-528. https://doi.org/10.1111/j.15406261.1988.tb03952.x

11. Brigham, E.F., and Ehrhardt, M. C. (2002). Financial Management, Theory and Practice (10thed ed.). Thomson Learning, Inc.

12. Brigham. Eugene F. and Joel F. Houston. (2009). Fundamentals of Financial Management. 215. https://doi.org/10.18860/ling.v5i1.609

13. Brigham \& Joel, 2009. (2009). Fundamentals of Financial Management. In Fundamentals of Financial Management (Tenth Edit, p. 101). Salemba Empat.

14. Brigham dan Joel F. Houston. (2011). Fundamentals of Financial Management. 2011.

15. Brigham, E. F. dan J. F. H. (2010). DasarDasar Manjemen Keuangan (Edisi 11, Vol. 1, Issue 1, p. 150). Salemba Empat. 
Ulfi Nurfaeda et.al. Role analysis of debt equity ratio on dividend payout ratio, stock return and earning per share with firm size and return on equity as intervening variable (case study of infrastructure companies listed in Indonesia stock exchange year of 2015-2019).

16. Bringham, Eugene F dan Weston, J. F. (2011). Dasar-dasar Manajemen Keuangan. 2011.

17. Carlo, M. A. (2014). Pengaruh Return on Equity, Dividend Payout Ratio, Dan Price To Earnings Ratio Pada Return Saham. EJurnal Akuntansi Universitas Udayana, 7(1), 151-164.

18. Copeland, T. E., Weston, A., \& Fred, J. (1999). Manajemen Keuangan. 1999.

19. Dwi, S., Dwi, D., \& Rachmawati, L. (2020a). Analisis Faktor-Faktor Yang Mempengaruhi Return Saham Dengan Profitabilitas Sebagai Variabel Intervening. 1(1).

20. Dwi, S., Dwi, D., \& Rachmawati, L. (2020b). Jurnal Akuntansi dan Manajemen Keuangan Analisis Faktor-Faktor Yang Mempengaruhi Return Saham Dengan. 1(1).

21. Eka Susilawati. (2014). Pengaruh Rasio Likuiditas, Rasio Solvabilitas, Dan Rasio Profitabilitas Terhadap Earning Per Share (Study Kasus Pada Perusahaan Manufaktur Yang Terdaftar Di Bursa Efek Indonesia Periode 2008-2011).

22. Eriotis, N. (2011). The Effect Of Distributed Earnings And Size Of The Firm To Its Dividend Policy: Some Greek Data. International Business \& Economics Research Journal (IBER), 4(1), 67-74. https://doi.org/10.19030/iber.v4i1.3568

23. Fahmi, I. (2013). Introduction to Financial Management. In Alfabeta. Alfabeta.

24. Fama, E. F., \& French, K. R. (2007). Taxes, Financing Decisions, and Firm Value. The Journal of Finance. The Journal of Finance, 53(3), 819-843.

25. Farrukh, K., Irshad, S., Shams Khakwani, M., Ishaque, S., \& Ansari, N. (2017). Impact of dividend policy on shareholders wealth and firm performance in Pakistan. Cogent Business and Management, 4(1), 111.

https://doi.org/10.1080/23311975.2017.140 8208

26. Firmansyah, T. Y., Dian, U., \& Semarang, N. (2010). Analisis Pengaruh Cash Position, Debt To Equity Ratio, Return On Assetsterhadap Deviden Payout Ratio (studi pada perusahaan manufaktur yang terdaftar pada BEI periode 2008-2010).

27. Franco Modigliani and Merton H. Miller. (1958). The American economic. 48(3), 261-297.
28. Fred, Weston dan Copeland, T. E. (2012). Financial Manajemen and Analysis. 22(3), 2005-2007.

29. Gleason et al. (2015). The interrelationship between culture, capital structure, and performance: Evidence from European retailers. Journal of Business Research, 50(2), 185-191.

https://doi.org/10.1016/S0148-

2963(99)00031-4

30. Gordon, M. (1956). Distrribution of Income of Corporations Among Dividend, Retained Earning and Taxes. 1956.

31. Goyal, A. M. (2013). Impact of Capital Structure on Performance of Listed Public Sector Banks in India. International Journal of Business and Management Invention ISSN (Online, 2(10), 35-43. www.ijbmi.org

32. Gugler, K. P., Mueller, D. C., \& Yurtoglu, B. B. (2011). Corporate Governance and the Determinants of Investment. SSRN Electronic Journal. https://doi.org/10.2139/ssrn.1020317

33. Hanafiah, M. A. L. I. (2014). Pengaruh Current Ratio, Quick Ratio, Inventory Turnover, Total Aset Turnover, Debt To Equity Ratio Tehadap Earning Per Share Pada Perusahaan Industri Barang Konsumsi Yang Terdaftar Di Bursa Efek Indonesia Periode 2009 - 2012.

34. Hanani, A. I. (2011a). Analisa Pengaruh Earning Per Share (EPS), Return On Equity (ROE), dan Debt To Equity ratio (DER) Terhadap Return Saham Perusahaan Perusahaan Dalam Jakarta Islamic Index (JII). Universitas Diponogoro.

35. Hanani, A. I. (2011b). Analisis Pengaruh Earning PER Share (EPS), Return on Equity (ROE), dan Debt to Equity Ratio (DER) terhadap Return Saham pada PerusahaanPerusahaan dalam Jakarta Islamic Index (JII) Periode Tahun 2005-2007. Jurnal Ekonomica, 6(4), 1-26. http://eprints.undip.ac.id/29964/

36. Inka et al. (2013). The Effect of Price to Book Value ( PBV ), Dividend Payout Ratio ( DPR ), Return on Equity ( ROE ), Return on Asset ( ROA ), and Earning Per Share ( EPS ) Toward Stock Return of LQ 45 for the Period of 2006-2011. Review of Integrative Business and Economics Research, 2(2), 22-44. http://search.proquest.com/docview/151331 5176/abstract/27EBF2F471EF45AAPQ/2?a ccountid $=38628 \#$ 
Ulfi Nurfaeda et.al. Role analysis of debt equity ratio on dividend payout ratio, stock return and earning per share with firm size and return on equity as intervening variable (case study of infrastructure companies listed in Indonesia stock exchange year of 2015-2019).

37. Ismi, N., Cipta, W., \& Yulianthini, N. N. (2016). Analisis Pengaruh Debt To Equity Ratio Dan Firm Size Terhadap Return on Equity Pada CV. Dwikora Usaha Mandiri. 4(1), 1-9.

38. Ivo Welch. (2013). Author ( s ): Ivo Welch Capital Structure and Stock Returns. 112(1), 106-132.

39. Jaara, B., Alashhab, H., \& Jaara, O. (2018). The Determinants of Dividend Policy for Non-Financial Companies in Jordan. International Journal of Economics and Financial Issues, 8(2), 198-209.

40. Jane chemutai, Dr.Caroline Ayuma, D. Y. (2017). Pengaruh Rasio Keuangan Terhadao Harga Saham Perusahaan LQ 45 Periode 2011-2015. 2017, 21(4), 35-49.

41. Jensen, M.C., dan W. H. M. (1976). The Theory of The Firm: Managerial Behaviour, Agency Cost, and Ownership Structure. 1976.

42. Jogiyanto. (2009). Portfolio Theory and Investment Analysis . Sixth Edition . BPFE . Yogyakarta. 2009.

43. Kasmir. (2010). Pengantar Manajemen Keuangan.

44. Kasmir. (2011). Analysis of Financial Statements. In Analysis of Financial Statements. Raja Grafindo Persada.

45. Kasmir, 2012. (2012). Analisis Laporan Keuangan. PT. Raja Grafindo Persada.

46. Khan, W., Naz, A., Khan, M., Khan, W. K. Q., \& Ahmad, S. (2013). The Impact of Capital Structure and Financial Performance on Stock Returns "A Case of Pakistan Textile Industry.” Middle East Journal of Scientific Research, 16(2), 289-295. https://doi.org/10.5829/idosi.mejsr.2013.16. 02.11553

47. Kong, H., Korea, S., Angeles, L., Ida, M., \& Studies, C. (2014). Editorial Board. International Journal of Infectious Diseases, 27(0), https://doi.org/http://dx.doi.org/10.1016/S12 01-9712(14)01628-2

48. Kowalewski, O., Stetsyuk, I., \& Talavera, O. (2011). Corporate Governance and Dividend Policy in Poland. SSRN Electronic Journal, 1-35. https://doi.org/10.2139/ssrn.986111

49. Kowalewski, S. and T. (2007). Do Corporate Governance and Ownership Determine Dividend Policy in Poland?

50. Kristina et al. (2017). Analisis Pengaruh Firm Size, DER , Asset Growth , ROE,EPS,
Quick Ratio dan Past Dividend terhadap Dividend Payout Ratio. Diponegoro Journal of Management, 6(3), 1-13.

51. Kumala et al. (2014). Pengaruh Kinerja Keuangan, Ukuran Perusahaan Dan Arus Kas Operasi Terhadap Earnings Per Share. DIPONEGORO JOURNAL OF ACCOUNTING Http://EjournalS1.Undip.Ac.Id/Index.Php/Accounting Volume, 3, 1-11.

52. Kumala Shinta. (2014a). Pengaruh Kinerja Keuangan, Ukuran Perusahaan Dan Arus Kas Operasi Terhadap Earnings Per Share (Studi Empiris Pada Perusahaan Manufaktur yang terdaftar di Bursa Efek Indonesia Tahun 2010-2012).

53. Kumala Shinta, H. L. (2014b). Arus Kas Operasi Terhadap Earnings Per Share. DIPONEGORO JOURNAL OF ACCOUNTING Http://EjournalS1.Undip.Ac.Id/Index.Php/Accounting Volume, 3, 1-11.

54. Kumala Shinta, H. L. (2014c). Pengaruh Kinerja Keuangan, Ukuran Perusahaan Dan Arus Kas Operasi Terhadap Earnings Per Share.

55. Kusumajaya, D. K. O. (2011). Pengaruh Struktur Modal dan Pertumbuhan Perusahaan terhadap Profitabilitas dan Nilai Perusahaan pada Perusahaan Manufaktur di Bursa Efek Indonesia. Unpublished Thesis. Universitas Udayana, 1-132.

56. lawrence O Karani. (2015). an Evaluation of Factors Affecting Dividend. An Evaluation of Factors Affecting Dividend Pay Out Ratio of Locally Owned Commercial Banks in Kenya.

57. Lia. (2017). Analisis Pengaruh Rasio Likuiditas, Leverage, Dan Profitabilitas Terhadap Dividend Payout Ratio (DPR) Dengan Firm Size Sebagai Variabel Intervening Pada Perusahaan Manufaktur Yang Terdaftar Di Bursa Efek Indonesia Periode Tahun 2012-2016. 1.

58. Lie et al, 2018. (2018). Operational And Financial Strategies For Peking Duck Breeding Start Up Business Integrated With Eco-Green. 4(April), 323-333.

59. Lintner, J. (1962). Dividends, Earning, Leverage, Stock Prices, and the Supply of Capital to Corporate. Parasitology of Fishes., 147004(1905), 1-21. https://scihub.tw/10.1002/iroh.19620470121 
Ulfi Nurfaeda et.al. Role analysis of debt equity ratio on dividend payout ratio, stock return and earning per share with firm size and return on equity as intervening variable (case study of infrastructure companies listed in Indonesia stock exchange year of 2015-2019).

60. Lucas, D. J., \& Mcdonald, R. L. (1990). Equity Issues and Stock Price Dynamics. XLV(4), 1019-1043.

61. Mais, R. G. (2004). Pengaruh rasio-rasio keuangan utama perusahaan terhadap harga saham-saham perusahaan yang terdaftar di Jakarta Islamic Index tahun. 2004.

62. Margaretha, F. (2011). Manajemen Keuangan Untuk Manajer Non keuangan. 2011.

63. Marietta, U. (2013). Analisis Pengaruh Cash Ratio, Return On Assets, Growth, Firm Size, Debt to Equity Ratio Terhadap Dividend Payout Ratio: (Studi Pada Perusahaan Manufaktur Yang Terdaftar di Bursa Efek Indonesia Tahun 2008-2011). Diponegoro Journal of Management, 2(3), 1-11. s1.undip.ac.id/index.php/dbr http://ejournal-

64. Martani, D., \& Khairurizka, R. (2009). The effect of financial ratios, firm size, and cash flow from operating activities in the interim report to the stock return. Chinese Business Review, 08(06), 44-55. https://doi.org/10.17265/15371506/2009.06.005

65. Mayuni et al. (2018). Pengaruh Roa, Firm Size, Eps, Dan Per Terhadap Return Saham Pada Sektor Manufaktur Di Bei. 7(8), 40634093.

66. Mazviona at al. (2014). Does Firm Size Affect Stock Returns? Evidence From the Zimbabwe Stock Exchange.

67. Mehta, A. (2012). An Empirical Analysis of Determinants of Dividend Policy - Evidence from the UAE Companies. Global Review of Accounting and Finance, 3(1), 18-31.

68. Michell Suharli. (2006a). Studi Empiris Mengenai Pengaruh Profitabilitas, Leverage, Dan Harga Saham Terhadap Jumlah Dividen Tunai (Studi pada Perusahaan yang Terdaftar di Bursa Efek Jakarta Periode 2002-2003).

69. Michell Suharli. (2006b). Studi Empiris Mengenai Pengaruh Profitabilitas, Leverage, Dan Harga Saham Terhadap Jumlah Dividen Tunai (Studi pada Perusahaan yang Terdaftar di Bursa Efek Jakarta Periode 2002-2003). Jurnal Manajemen, Akuntansi \& Sistem Informasi, 6(2), 243-256.

70. Michell Suharli dan Sofyan S.Harahap. (2004). Studi Empiris Terhadap Faktor Penentu Kebijakan Jumlah Dividen.
71. Misra, A., \& Anil, K. (2010). Deviden Policy Determinants of Indian Service Sector:A Factorial Analysis. 1, 24-42.

72. Murhadi, W. (2013). Analisis Laporan Keuangan Proyeksi Dan Valuasi Saham. Salemba Empat.

73. Myers, S.C and Majluf, N. S. (1984). Corporate Financing and Investment Decisions When Firm Have Information that Investor Do Not Have. 13, 1984.

74. Nayeem Abdullah, M. (2015). The Impact of Financial Leverage and Market Size on Stock Returns on the Dhaka Stock Exchange: Evidence from Selected Stocks in the Manufacturing Sector. International Journal of Economics, Finance and Management Sciences, 3(1), 10. https://doi.org/10.11648/j.ijefm.20150301.1 2

75. Nerviana, R. (2016). The effect of financial ratios and company size on dividend policy. The Indonesian Accounting Review, 5(1), 23. https://doi.org/10.14414/tiar.v5i1.486

76. Nishat, M. \& Bilgrami, N. (1994). Who pays dividend - An exploratory analysis of firms listed with Karachi stock market.

77. Nizar Al-Malkawi, H. (2007). Determinants of Corporate Dividend Policy in Jordan: An Application of the Tobit Model. Journal of Economic and Administrative Sciences, 23(2), $\quad$ 44-70. https://doi.org/10.1108/1026411620070000 7

78. Nopiyah, W. (2017). Pengaruh Debt To Equity Ratio, Debt To Asset Ratio, Return On Asset, Dancurrent Ratio Terhadap Earning Per Share. 01(10).

79. Nugrahani, A. (2016). Pengaruh Kinerja Keuangan Dan Ukuran Perusahaan Terhadap Earning Per Share. Pendidikan Ekonomi, 5(1), 5.

80. Nurhikmawaty, D., Isnurhadi, I., Widiyanti, M., \& Yuliani, Y. (2020a). the Effect of Debt To Equity Ratio and Return on Equity on Stock Return With Dividend Policy As Intervening Variables in Subsectors Property and Real Estate on Bei. Edunomic Jurnal Pendidikan Ekonomi, 8(2), 72. https://doi.org/10.33603/ejpe.v8i2.3531

81. Nurhikmawaty, D., Isnurhadi, I., Widiyanti, M., \& Yuliani, Y. (2020b). The Effect of Debt To Equity Ratio and Return on Equity on Stock Return With Dividend Policy As Intervening Variables in Subsectors Property and Real Estate on Bei. Edunomic 
Ulfi Nurfaeda et.al. Role analysis of debt equity ratio on dividend payout ratio, stock return and earning per share with firm size and return on equity as intervening variable (case study of infrastructure companies listed in Indonesia stock exchange year of 2015-2019).

Jurnal Pendidikan Ekonomi, 8(2), 72. https://doi.org/10.33603/ejpe.v8i2.3531

82. Nurvi. (2015). Pengaruh Cash Position, Firm Size, Debt To Equity Ratio, Dan Return On Assets Terhadap Dividend Payout Ratio Pada Perusahaan Manufaktur Yang Terdaftar Di Bursa Efek Indonesia. 3(2), 54-67.

83. Prastowo \& Julianti. (2005). Analisis Laporan Keuangan Konsep dan Aplikasi.

84. Pribadi, A. S., \& Sampurno, R. D. (2012). Analisis Pengaruh Cash Position, Firm Size, Growth Opprtunity, Ownership, dan Return on asset terhadap Dividend Payout Ratio. Diponegoro Journal of Management, 1(4), 201-211.

https://ejournal3.undip.ac.id/index.php/djom /article/view/800/774

85. Pruitt, S. W., \& Gitman, L. J. (1991). The Interactions between the Investment, Financing, and Dividend Decisions of Major U.S. Firms. Financial Review, 26(3), 409430 . https://doi.org/10.1111/j.15406288.1991.tb00388.x

86. Puspita, V. (2012a). Pengaruh Profitabilitas, Leverage, Dan Ukuran Perusahaan Terhadap Return Saham (Studi Pada Perusahaan LQ-45 di Bursa Efek Indonesia).

87. Puspita, V. (2012b). Pengaruh Profitabilitas, Leverage, Dan Ukuran Perusahaan Terhadap Return Saham (Studi Pada Perusahaan LQ-45 di Bursa Efek Indonesia ).

88. Ross, S. A. (1977). the Determination of Financial Structure: the Incentive-Signaling Approach. 8, 1977.

89. Sartono, A. (2010). Manajemen Keuangan Teori dan Aplikasi.

90. Setiyono, E. (2016). Pengaruh Kinerja Keuangan Dan Ukuran Perusahaan terhadap Return Saham Perbankan. Pendidikan Ekonomi, 5(1), 5.

91. Sinabutar, A., \& Nugroho, A. B. (2015). Dividend Payout Ratio in Indonesian Consumer Goods Industry: Panel Analysis and Determinant Factors in 2004-2013. Journal of Business and Management, 4(4), 453-464.

92. Sinaga, R. V. (2019). Pengaruh Debt To Equity Ratio (Der), Return on Asset (Roa), Earning Pershare (Eps), Price Earning Ratio (Per) Terhadap Return Saham Pada Perusahaan Jasa Perhotelan Yang Terdaftar Di Bursa Efek Indonesia. Journal of
Chemical Information and Modeling, 53(9), 1689-1699.

93. Smart, Scoot B, William L megginson, Lawrence J, G. (2004). Corporate Finance. Thomson South Western.

94. Sudana, M. I. (2011). Manajemen Keuangan Perusahaan. 2011.

95. Sugiyanto. (2019). Analisis Pengaruh Return On Assets, Debt To Equity Ratio, Earning Per Share Dan Firm Size Terhadap Market Value Added (Studi Kasus Perusahaan Konstruksi Bangunan Di Bursa Efek Indonesia Tahun 2013-2017). 5-10.

96. Sulistiyowati Indah, et al. (2010). Pengaruh Profitabilitas, Leverage, dan Growth Terhadap Kebijakan Dividen dengan Good Corporate Governance sebagai Variabel Intervening. Pengaruh Profitabilitas, Leverage, Dan Growth Terhadap Kebijakan Dividen Dengan Good Corporate Governance Sebagai Variabel Intervening, $1-23$.

97. Susilawati, E. (2014). Pengaruh Rasio Likuiditas, Rasio Solvabilitas, Dan Rasio Profitabilitas Terhadap Earning Per Share. 2(1).

98. Sutrisno. (2009). Financial Method Theory. Concepts and Applications. In Financial Method Theory. Concepts and Applications (Tenth Edit, p. 15). Salemba Empat.

99. Taani et al. (2011). The Effect of Financial Ratios, Firm Size, and Cash Flow From Operating Activities on Earnings Per Share. International Journal Of Social Science and Humanity Studies.

100. Thomsett, 2012. (2012). Real Estate Market Valuation and Analysis. Journal of Property Investment \& Finance, 25(5), 532533.

https://doi.org/10.1108/1463578071077671 0

101. Tikupadang, F. K., Saerang, D. P. E., \& Afandi, D. (2016). Analisis Penerapan Akuntansi Kontrak Konstruksi Dalam Penyajian Laporan Keuangan Pada PT. Sederhana Karya Jaya Di Manado. Jurnal Berkala Ilmiah Efisiensi, 16(04), 59-69.

102. Umar et al., 2009. (2009). Sistem Informasi Akuntansi Pada Perusahaan Jasa Kontraktor Cv. Cipta Adhi Jaya ( Studi Kasus Pada Pembangunan Guest House, Jl. Ngesrep Barat, Semarang). 1-20.

103. Untu, V., Tommy, P., \& Legiman, F. (2015). Faktor-faktor Yang Mempengaruhi Return Saham Pada Perusahaan 
Ulfi Nurfaeda et.al. Role analysis of debt equity ratio on dividend payout ratio, stock return and earning per share with firm size and return on equity as intervening variable (case study of infrastructure companies listed in Indonesia stock exchange year of 2015-2019).

Agroindustry Yang Terdaftar Di Bursa Efek Indonesia Periode 2009-2012. Jurnal Riset Ekonomi, Manajemen, Bisnis Dan Akuntansi, 3(3), 382-392.

104. Utami, W. (2006). Analisis Determinan Audit Delay Kajian Empiris di Bursa Efek Jakarta.

105. Werner and Jones. (2003). Werner, M. L., Jones, K.H. (2003). Introduction to Financial Accounting: A user perspective, (3 rd edition), Japan: Pearson Education Limited.

106. Wiagustini, N. L. P. (2010). DasarDasar Manajemen Keuangan. Universitas Udayana.

107. Yuliandri et al. (2012). Analisis Pengaruh Ukuran Perusahaan dan Financial Laverage Terhadap Earnings per share (Penelitian pada Perusahaan Manufaktur di Bidang Makanan dan Minuman yang
Terdaftar di Bursa Efek Indonesia Periode 2009-2011).

108. Zeitun, R., \& Tian, G. (2007). Capital structure and corporate performance: evidence from Jordan. Australasian Accounting, Business and Finance Journal, 1(4), 40-61. https://doi.org/10.14453/aabfj.v1i4.3

How to cite this article: Nurfaeda U, Syah TYR. Role analysis of debt equity ratio on dividend payout ratio, stock return and earning per share with firm size and return on equity as intervening variable (case study of infrastructure companies listed in Indonesia stock exchange year of 2015-2019). International Journal of Research and Review. 2021; 8(11): 293-310. DOI: https://doi.org/10.52403/ijrr.20211138 